\title{
Usefulness of morphological characters for infrageneric classification of Elatostema (Urticaceae)
}

\author{
J.T. Hadiah¹, B.J. Conn²
}

Key words

Elatostema

morphology

phylogeny

Procris

Urticaceae

\begin{abstract}
In 1896, Hans Hallier was the first author to reduce the two genera Pellionia and Procris to subgeneric status within the genus Elatostema (Urticaceae). In 1935 and 1936, Hilde Schröter and Hubert Winkler proposed the following four subgenera: subg. Elatostema, subg. Elatostematoides, subg. Pellionia and subg. Weddellia, while maintaining Procris as a distinct genus. More recently, Wang (1980a) rejected Schröter and Winkler's subgeneric classification of Elatostema and proposed a sectional and serial infrageneric classification of recognising as sections Androsyce, Elatostema, Laevisperma, Pellionioides and Weddellia (as 'Weddelia'). He maintained both Pellionia and Procris as distinct genera. All previous researchers of Elatostema and related taxa primarily based their classifications on the morphology of leaves, stipules, inflorescence and receptacle. Our analysis, based on similar morphological characters, does not support the previous infrageneric classifications. Procris forms a monophyletic clade, nested within a clade consisting of several species of Elatostema subg. Pellionia and one of subg. Elatostematoides. Elatostema auriculatifolium (subgeneric classification unclear) is also included within this clade. This clade is sister to the E. latifolium-E. tsoongii pair of species (also subg. Pellionia), subg. Elatostema (the remaining species of this subgenus), species of subg. Weddellia and E. rostratum (subg. Elatostematoides). Elatostema subg. Weddellia is paraphyletic within subg. Elatostema. The recognition of Elatostematoides, Pellionia and Procris as distinct genera is not supported.
\end{abstract}

Published on 30 October 2009

\section{INTRODUCTION}

Elatostema J.R.Forst. \& G. Forst. (Urticaceae) is a taxonomically problematic genus of c. 300 species that is widespread throughout the tropical, subtropical and subtemperate regions of Africa through SE Asia, Australasia to Polynesia. The identification and infrageneric classification of Elatostema has traditionally been based on morphological characteristics (for example, Robinson 1910, Winkler 1922, Schröter \& Winkler 1935, Wang 1980a, b, Weddell 1854, 1856, 1857, 1869). The characters used in this phylogenetic analysis have, in part, been based on the morphological features used by these researchers. However, several features have been re-interpreted so that they can be scored more consistently than is possible for many of the more subjectively defined character states used by previous researchers (for example, venation patterns). A few additional characters, not used by previous workers, have also been included (for example, the form of nanophylls). Multimetric overlapping characters (that is, characters defined by dimensions rather than non-overlapping codes) have been included by conversion to non-overlapping or minimal overlapping characters states using the divergence coding technique of Almeida \& Bisby (1984). The following multi-metric characters that were converted include: plant height, petiole length, lamina length, lamina width, lamina length to width ratio, lamina asymmetry, leaf vein pairs and male tepal length. However, stipule length was not used because species with non-persistent stipules usually loose their stipules while they are young and these are frequently smaller than, and hence, not comparable with the older, persistent stipules of other species. Up to five herbarium specimens of each species included in this study were analysed to cover the morphological variation within each species.

\footnotetext{
Center for Plant Conservation, Bogor Botanic Gardens, Jl. Ir. H. Juanda 13, Bogor 16122, Indonesia.

2 National Herbarium of New South Wales, Mrs Macquaries Road, Sydney NSW 2000, Australia.
}

\section{Morphological characters used by Robinson (1910)}

In species of Elatostema (s.s.), the involucral bracts are present and enclose the staminate and pistillate flowers, whereas involucral bracts are absent in Pellionia and Procris. The pistillate flowers of Pellionia are arranged in condensed inflorescences, whereas those of Procris are arranged on a fleshy receptacle. The inflorescence of staminate flowers of Pellionia and Procris are always openly paniculate (Qi et al. 2003, Ariyanti 2004, respectively). Robinson (1910) emphasised the usefulness of the inflorescence and pistillate flowers for differentiating species of Elatostema, Elatostematoides, Procris and Pellionia. Robinson (1911) concluded that merosity of the perianth of pistillate flowers was taxonomically useful for distinguishing Elatostema, Elatostematoides, Pellionia and Procris, with Elatostema characterised by 3-partite pistillate flowers, although 2- and 4-partite perianth flowers also appear to be present in otherwise 3-partite flowered inflorescences. Elatostematoides was characterised as having a 5-partite pistillate perianth. However, Robinson mistook the staminodes for the perianth. The perianth is much reduced or absent in all species of Elatostema s.str. (Schröter \& Winkler 1935). The pistillate perianth of Pellionia is 4- or 5partite and as long as the ovary. The pistillate perianth of Procris is 3- or 4-partite, deeply divided, widely spreading, and shorter than or as long as the ovary. Thus, Pellionia is indistinguishable from some species of Procris and Elatostematoides.

The presence or absence of staminodes in pistillate flowers is thus not useful for distinguishing the genera discussed by Robinson. However, this character is taxonomically useful, at a tribal level, for distinguishing the Elatostemeae from all other tribes in the family. The pistillate flowers of all genera of Elatostemeae have staminodes, whereas the pistillate flowers of all other tribes lack staminodes (Friis 1993). We included perianth merosity in our dataset to test its usefulness in defining taxon relationships. 


\section{Morphological characters used by Schröter \& Winkler (1935)}

Schröter \& Winkler (1935) provided a comprehensive discussion of morphological characters that they regarded as taxonomically useful for understanding Elatostema and for distinguishing the four subgenera recognised by them, namely subg. Elatostema, subg. Elatostematoides, subg. Pellionia and subg. Weddellia. The morphological characters used by them included features of habit, anisophylly, phyllotaxy, leaf and venation characteristics, cystoliths, stipules and reproductive features (including inflorescence structure, floral and fruiting characteristics). Although promoting the usefulness of these characters, they recognised that the taxonomic circumscription of these four subgenera was often unclear.

The characters and character states discussed by Schröter \& Winkler (1935) include:

\section{Vegetative features}

Herbs, subshrubs and shrubs - Members of Elatostema are mostly herbs or subshrubs, rarely shrubs. The majority of taxa of subg. Weddellia and subg. Elatostema are fleshy herbs, whereas many of the species of subg. Pellionia and subg. Elatostematoides have more sclerenchymatous cells in the stem during later growth stages. Therefore, some of these species appear slightly 'woody', here referred to as subshrubs. According to Schröter \& Winkler (1935) there are many subshrubs or shrubs in subg. Pellionia, but they did not provide specific examples. Species of subg. Elatostematoides are all subshrubs.

\section{Leaf characteristics}

Anisophylly - The leaf-pairs at each node are characteristically very unequal in size in Elatostema such that the foliage appears strongly anisophyllous. This anisophylly is also present in other Urticaceous genera, including Pilea. Schröter \& Winkler (1935) considered the presence or absence of the nanophyll (small leaves) and its shape as useful taxonomic characters in distinguishing subgeneric groupings within Elatostema. In subg. Weddellia, all species have shortly petiolate nanophylls, whereas many species in the remaining subgenera lack nanophylls. In subg. Elatostema, only three species have nanophylls (namely, E. ambiguum, $E$. bulbiferum and E. burmanicum). Sessile, minute, more or less linear and readily caducous nanophylls are found in a few species of subg. Elatostematoides (for example, a few species of the Elatostema rostratum group). Finally, in subg. Pellionia, some species have relatively large, green leaf-like nanophylls (for example, E. filicinum, E. raapii and E. sinuatum, and), some others have minute nanophylls (for example, E. hallieri and E. variolaminosum).

The form of the nanophylls is relatively consistent throughout the genus but has not been used as a taxonomic character by previous researchers. When nanophylls are absent, the normal larger leaves (macrophylls) are spirally arranged. The macrophylls vary in shape from obovate, elliptic, narrowly ovate to ovate or rarely roundish. All normal larger leaves that occur in Elatostema and other Urticacean taxa are here referred to as macrophylls to distinguish them from the much smaller nanophylls inserted at the same nodes. Goebel (1928) observed 'rudimentary leaves' (nanophylls) on newly germinated plants of $E$. sessile (type species of genus), that became fused with the stipule during later stages of growth.

Phyllotaxy — Schröter \& Winkler (1935) described the phyllotaxy of Elatostema as opposite, decussate, similar to other members of the family. However, since one leaf of the leafpair at each node is much reduced compared to the other leaf, this gives the appearance of an alternate/spiral arrangement.

Leaf shape symmetry - The width of the lamina of the macrophyll on each side of the central axis (from midvein to margin) is unequal.

Leaf base symmetry - The base of the broader side of the macrophyll's lamina usually exceeds the length of the narrower side. Occasionally the base is slightly cordate (for example, $E$. hastatum and $E$. reticulatum) to more fully cordate (rounded on both sides) (for example, E. griffithianum).

Leaf venation - Robinson (1910) concluded that it was not possible to categorize the venation patterns found in Elatostema because they were too variable. In contrast, Schröter \& Winkler (1935) considered venation patterns taxonomically
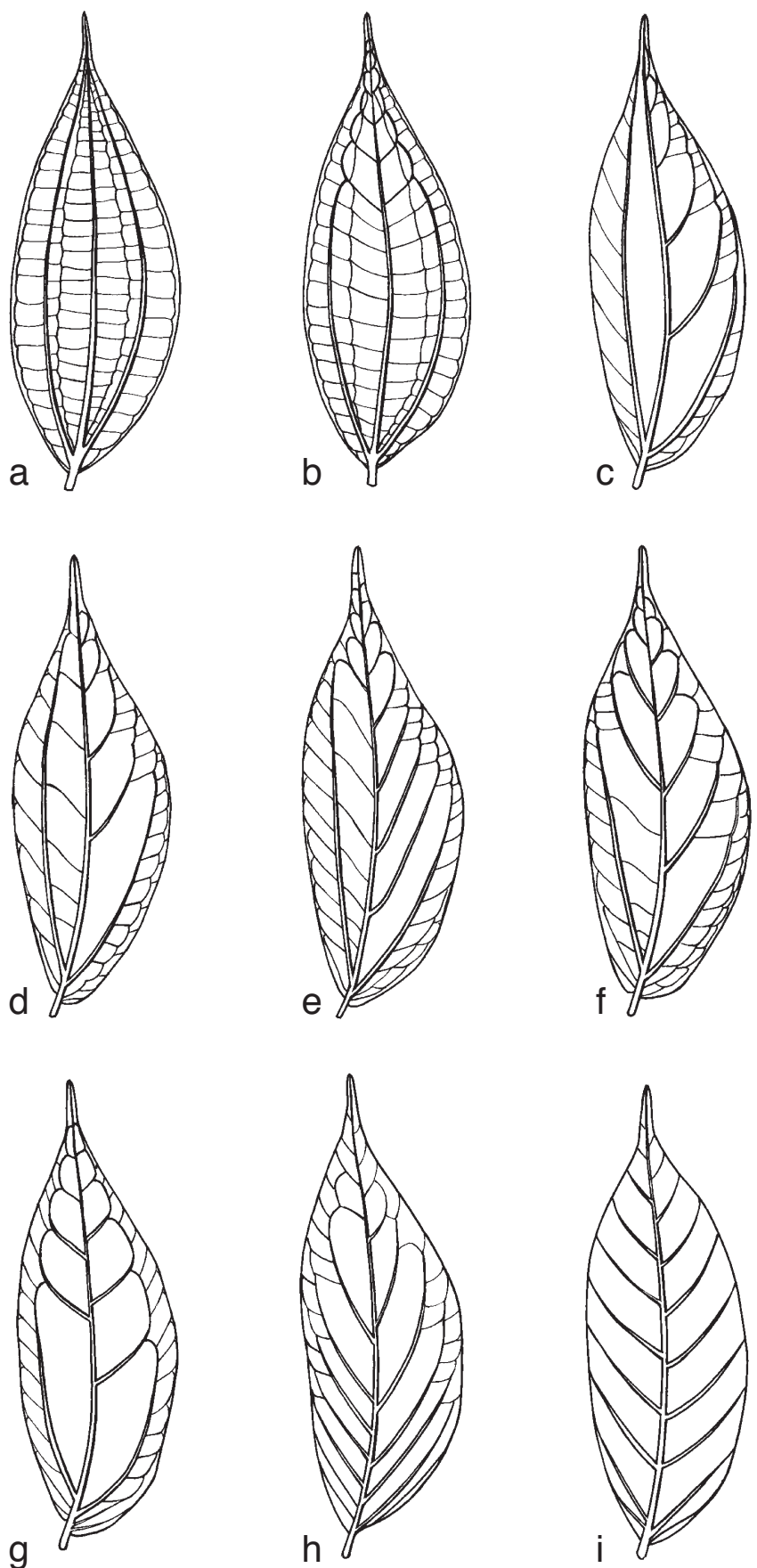

Fig. 1 Venation types redrawn from Schröter \& Winkler (1935: f. 3-11). a. Type I, triplinervis; b. Type II, triplinervis supernis penninervis; c. Type III, semi-penninervis; d. Type IVa, semi-penninervis apex penninervis; e. Type $\mathrm{IVb}$, semi-penninervis supernis penninervis; f. Type IVd, semi-penninervis supra medium penninervis; g. Type IVe, subpenninervis; h. Type IVe, subpenninervis; i. Type $\mathrm{V}$, penninervis. 

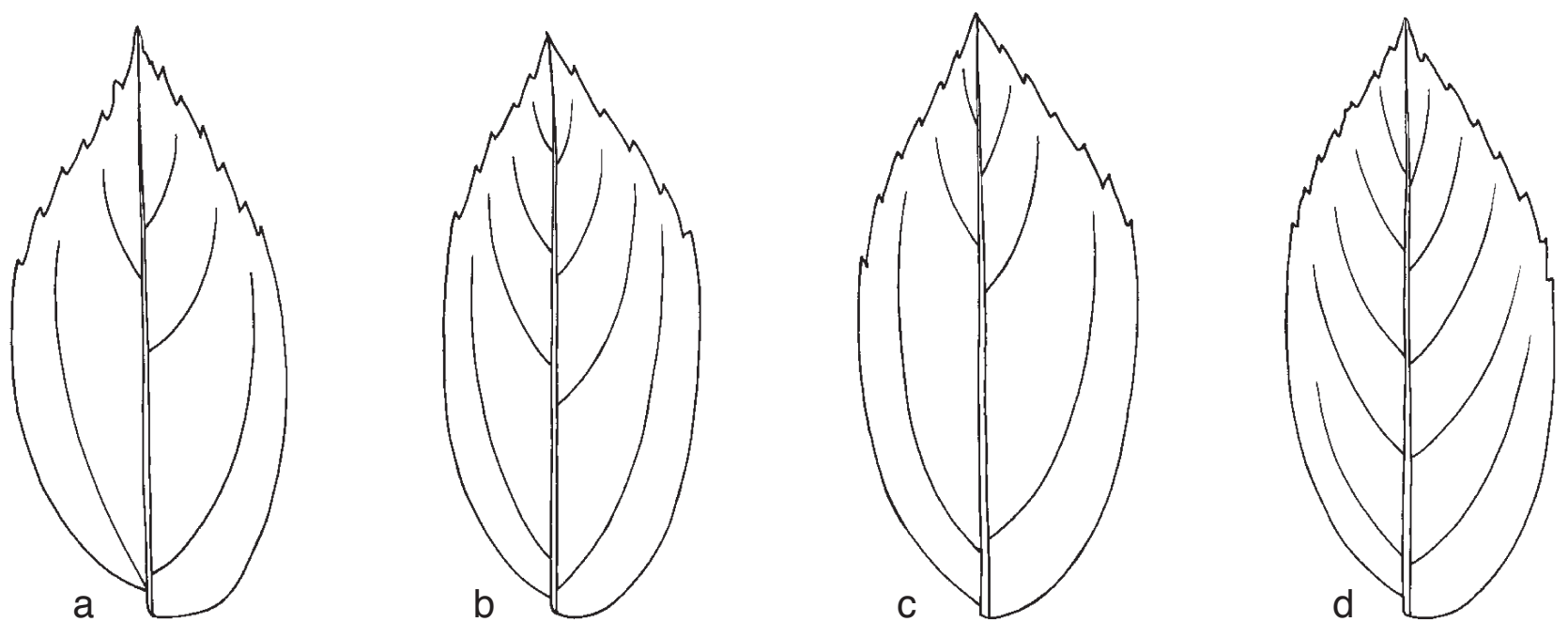

Fig. 2 Classification of venation types as used by Wang (1980); figures redrawn from Wang (1980: 3). a. 3-nerved; b. semi-3-plinerved; c. 3-plinerved; d. penninerved.

useful, and the variability relatively small. They recognised the following five venation types (Fig. 1):

Type I 3-plinerved (major secondary veins are inserted near base of lamina and converge near apex).

Type II 3-plinerved with distal part of lamina pinnately nerved (as type I, but major secondary veins in distal third replaced by pinnate venation). Pilea is characterised by type I and II. Neither type is found in Elatostema.

Type III semi-pinnately nerved with the two basal lateral secondary veins unequal in length and direction. Only one vein extends to the apex, the other vein is much shorter, directed more towards the margin, and has more lateral secondary veins on this same side. This type III venation (another modification of type I) is found in subg. Elatostematoides and in some species of Pellionia.

Type IV semi-pinnately to subpinnately nerved, with five subtypes which appear to be minor variants.

Type $\mathrm{V}$ pinnately nerved on both sides of the central. This type is found in a few species of Pilea, in many species of Pellionia and all Procris species, plus a few species of Elatostema s.str. (for example, E. macrophyllum and E. rugosum).

In his work on the systematics of Chinese species of Elatostema, Wang (1980a) simplified the Schröter \& Winkler (1935) classification of venation patterns (reproduced here as Fig. 2). $\mathrm{He}$ recognised four character states, namely 3-nerved, semi3-plinerved, 3-plinerved and penninerved.

Cystoliths - Cystoliths are present in all species of the Urticaceae (Bigalke 1933) and their form and distribution have been found to be taxonomically useful for distinguishing infrafamilial groups, even if only as secondary characters. Within the large genus Elatostema, they are, at least, superficially relatively homogeneous. A detailed study of the taxonomic usefulness of cystoliths within Elatostema has not been included in this study; however, additional research is recommended.

Stipules - In Elatostema, the stipules are usually membranous, occasionally somewhat fleshy, and usually glabrous. They mostly vary from narrowly ovate (lanceolate) to almost linear (often referred to as linear-lanceolate), initially often shorter than mature stipules. Some large-leaved species (for example, E. fagifolium, E. nemorosum and E. smilacinum) have large stipules of 30-50 mm long. Elatostema sinuatum and related species possess short to minute stipules of 1-2 $\mathrm{mm}$ long (on macrophylls).

\section{Reproductive features}

Inflorescence

The basic inflorescence structure of Urticaceae is cymose, either dichasial or monochasial (Golenkin 1894, Bernbeck 1932). Schröter \& Winkler (1935) placed considerable taxonomic importance on the various types of inflorescence exhibited by the members of the tribe Elatostemeae.

Structure of inflorescence - The inflorescences vary from relatively loosely arranged clusters of flowers (for example, as found in subg. Elatostematoides and subg. Pellionia) to more crowded inflorescences (for example, E. velutinum and E. undulatum, both subg. Pellionia). The inflorescence of the former group lacks an involucre, whereas the latter group has a slightly developed involucre of bracts. Schröter \& Winkler (1935) regarded the arrangement of flowers as a very important character for delimiting subgenera of Elatostema.

The male and female inflorescences are 'divided' into a series of compartments with the underlying cymose arrangement maintained (Weddell 1856, Schröter \& Winkler 1935: f. 17, 29, 30). Although the latter regarded the female inflorescence of Elatostema vittatum (subg. Elatostematoides) as compartmentalised ('ordered') (their f. 17), we scored it as 'unordered' because the indistinct compartmentalisation meant that the scoring of this character was problematic.

Schröter \& Winkler (1935: f. 18-28) discussed and illustrated the extent of fusion between involucral bracts. We did not use this character because it proved difficult to measure consistently.

Receptacle of inflorescence - The inflorescences of Elatostema subg. Elatostematoides, subg. Pellionia and the genus Pilea lack a receptacle (Schröter \& Winkler 1935), whereas the receptacle is present for members of subg. Elatostema, subg. Weddellia and the female inflorescences of Procris (absent in male inflorescences of the latter genus).

As for several other morphological characters that Schröter \& Winkler (1935) regarded as taxonomically useful, none of their inflorescence features uniquely describe any of the taxa listed in Table 1. There is considerable overlap between the characterstates of most characters used to distinguish these taxa. 
Table 1 Summary of taxonomically useful inflorescence characters based on usage by Schröter \& Winkler (1935: 17 p.p.).

\begin{tabular}{|c|c|c|c|c|c|c|}
\hline Characters & Pilea & Elatostematoides & Pellionia & Elatostema & Weddellia & Procris \\
\hline \multicolumn{7}{|c|}{ Male inflorescence } \\
\hline Form & \pm loose & $\begin{array}{l}\text { slightly crowded or } \\
\text { loose }\end{array}$ & $\begin{array}{l} \pm \text { slightly crowded or } \\
\pm \text { loose }\end{array}$ & crowded & crowded & loose \\
\hline Shape & $\begin{array}{l}\text { openly } \\
\text { branched }\end{array}$ & $\begin{array}{l}\text { slightly head-like or } \\
\text { openly branched }\end{array}$ & $\begin{array}{l}\text { slightly head-like or openly } \\
\text { branched }\end{array}$ & $\begin{array}{l}\text { head-like (when slightly fused), or } \\
\text { disc-shaped (when mostly fused), } \\
\text { or concave (as in E. ficoides) }\end{array}$ & \pm disc-shaped & openly branched \\
\hline Receptacle & absent & absent & $\begin{array}{l}\text { absent (except slightly } \\
\text { developed in } E \text {. velutinum } \\
\text { and } E \text {. undulatum) }\end{array}$ & present & present & absent \\
\hline \multicolumn{7}{|c|}{ Female inflorescence } \\
\hline Form & \pm loose & crowded & $\begin{array}{l} \pm \text { slightly crowded or } \\
\pm \text { loose }\end{array}$ & crowded & crowded & crowded \\
\hline Shape & $\begin{array}{l}\text { openly } \\
\text { branched }\end{array}$ & slightly head-like & $\begin{array}{l}\text { slightly head-like or openly } \\
\text { branched }\end{array}$ & $\begin{array}{l}\text { head-like (when slightly fused), or } \\
\text { disc-shaped (when mostly fused), } \\
\text { or concave (as in E. ficoides) }\end{array}$ & \pm disc-shaped & globular \\
\hline Receptacle & absent & absent & $\begin{array}{l}\text { absent (except to a lower } \\
\text { extend in } E \text {. velutinum } \\
\text { and } E \text {. undulatum) }\end{array}$ & $\begin{array}{l}\text { present, distinct (except } E \text {. ambiguum, } \\
E \text {. bulbiferum, E. umbellatum } \\
\text { have no receptacles) }\end{array}$ & present & present \\
\hline
\end{tabular}

\section{MATERIAL AND METHODS}

\section{Taxon sampling}

The taxa of Elatostema used in this study represented each of the four subgenera of the genus recognised by Robinson (1910) and Schröter \& Winkler (1935), namely, subgenera Elatostema, Elatostematoides, Pellionia and Weddellia. Species of Pilea and Procris (both Elatostemeae) were included, along with representatives of the Boehmerieae, Parietarieae and Urticeae. Boehmeria calophleba and B. macrophylla were used to root the trees.

\section{Management of morphological data}

Measurement of morphological characters were recorded and managed in DeltaAccess software, v1.9 (Hagedorn 2005), with data exported in DELTA-format. These DELTA files were then converted into NEXUS formatted files using the NDE software (Page 2001). These data were then loaded directly into PAUP* v4.0b10 (Swofford 2002) for phylogenetic analyses.

\section{Choice and definition of characters}

We use morphological characters to evaluate the morphological support for the monophyly of the infrageneric groupings in Elatostema proposed by Schröter \& Winkler (1935, 1936). The choice of characters was based, in part, on the results of Robinson (1910) and Schröter \& Winkler (1935, 1936), and, to a lesser extent, on research on other members of the Urticaceae. A list of the morphological characters used in this study is given in Table 2. All characters were treated as ordered and polarised to minimise parallel gain (Kitching in Forey et al. 1992).

\section{Non-overlapping characters converted from overlapping characters}

Even though overlapping morphometric characters may be useful in defining taxa, the PAUP* v4.0b10 software (Swofford 2002), excludes overlapping characters. There is an implicit assumption in phylogenetic analysis that character states must be discrete (Pimentel \& Riggins 1987, Scotland in Forey et al. 1992) but the recognition of distinct character states in overlapping data is frequently difficult. Characters derived from overlapping morphometric data can be used in cladistic analysis (Ariyanti \& Conn 2005). However, the transforming of such data into discrete, non-overlapping states has been controversial. One concern with coding overlapping data into discrete, nonoverlapping states is that this may result in an unacceptable level of data distortion (Chappill 1989). However, Thiele \&
Ladiges (1988), Thiele (1993) and Ariyanti \& Conn (2005) maintain that morphometric data can provide useful information in phylogenetic analyses.

Divergence coding (Almeida \& Bisby 1984) uses box plots (or 'box-and-whisker' plot sensu Tukey 1977) to represent the median, 1st quartile and 3rd quartile values to separate overlapping data into non-overlapping character states. A box plot provides a simple graphical summary of a set of data. It shows a measure of central location (the median), two measures of dispersion (the range and inter-quartile range), the skewness (from the orientation of the median relative to the quartiles) and potential outliers (marked individually). The lines extending from the box ('whiskers') indicate the range of values within $1.5 \times$ inter-quartile range (Wilkinson et al. 1992). We converted quantitative character states to discrete values to eliminate or, at least, minimise the degree of overlap between the character states in the following way: each character was divided into non-overlapping states by placing the inter-quartile range into a single discrete state. Occasionally, characters of some taxa could not be assigned to a single discrete character state. These were recorded as having more than one character state. Five collections of each taxon were used to generate the distributions for the box plots based on minimum and maximum values of each over-lapping character. The following characters were recoded using the divergence coding technique: plant height; petiole length; lamina length; lamina width; lamina length to width ratio; veins number; length of tepals in male flowers. The codified values for each of these characters are listed in Table 2.

\section{Phylogenetic analyses}

Ten uninformative characters were deleted prior to analysis. Heuristic searches were conducted in PAUP* using tree bisection reconnection branch-swapping restricted to 100 trees per replicate and 1000 replicates of random taxon addition to search for multiple islands of most-parsimonious (MP) trees. Support for clades was estimated by decay analysis. These decay values were conducted in PAUP* with 100 replicates of random taxon addition on each constraint tree, using command files created in MacClade. The level of homoplasy was summarised by the Consistency Index excluding uninformative characters (Cl-u), Retention Index (RI) and Rescaled Consistency Index (RC).

All characters were initially equally weighted so that the greatest degree of congruence between as many characters as possible would distinguish the useful characters from the misleading ones. Once the parsimony analysis was completed, the 
Table 2 List of morphological characters used in this study, together with the character states recorded for each character. Characters 2 , 14, 16-18, 26 and 52 , are overlapping characters that have been converted to non-overlapping character states prior to phylogenetic analyses.

$$
\begin{aligned}
& \text { 1. habit } \\
& \text { a. herb (or subshrub) } \\
& \text { b. shrub } \\
& \text { c. tree }
\end{aligned}
$$

2. plant height (non-overlap)

$$
\begin{aligned}
& \text { a. up to } 1 \mathrm{~m} \text { high } \\
& \text { b. between } 1 \text { and } 4 \mathrm{~m} \\
& \text { c. more than } 4 \mathrm{~m}
\end{aligned}
$$

The plant height measurements were based on personal field observations, herbarium notes provided by botanical collectors or, less frequently, the measurement of the herbarium specimen when the whole plant was represented by the collection. More commonly, a combination of these data sources was used.

3. form
a. self-supporting (erect or suberect)
b. creeping

4. epiphyte/hemi-epiphyte
a. no
b. yes

5. sexuality

a. monoecious

b. dioecious

6. branched hairs
a. absent
b. present

7. stinging hairs
a. absent

b. present

8. internode

a. developed (elongate, distinct)

b. reduced (not visible)

9. stipules

a. caducous

b. persistent

10. stipule attachment
a. free

b. connate

11. stipule position
a. lateral (interpetiolar)

b. axillary (intrapetiolar)

12. leaf arrangement
a. opposite
b. subopposite
c. alternate

13. leaf petiole

a. sessile (petiole absent or less than $2 \mathrm{~mm}$ long)

b. petiolate (petiole at least $2 \mathrm{~mm}$ long)

14. leaf petiole length (non-overlap)
a. 0 (absent) $-11 \mathrm{~mm}$
b. $11-41 \mathrm{~mm}$
c. longer than $41 \mathrm{~mm}$

15. leaf lobing
a. not lobed
b. lobed

16. lamina length (non-overlap): length of lamina, from base to apex
a. less than $50 \mathrm{~mm}$

b. more than $50 \mathrm{~mm}$

17. lamina width (non-overlap): width at broadest part of lamina

a. less than $60 \mathrm{~mm}$

b. more than $60 \mathrm{~mm}$

18. lamina length: width ratio (non-overlap)
a. less than 2
b. more than 2

19. lamina symmetry: width comparison

a. unequal

b. equal

This character compares the width of the lamina on each side of central axis (often midvein). The comparison is made in the central $1 / 3$ of the lamina. Leaves are regarded as having an asymmetric lamina (hence, unequal) if the width of broadest side is at least 1.34 times the width of the narrowest side. Leaves with equally symmetric laminas (equal) have a 'width' ratio of less than 1.34. Aniso- phylly and leaf lamina asymmetry are frequently associated (Dengler 1999). Leaf asymmetry is often present in the Urticaceae; in some species it is subtle, whereas in others the leaf lamina is distinctly asymmetric. All species of Elatostema are characterised by having strongly asymmetric (unequal) leaf laminas.

20. leaf base

a. equal

b. oblique

21. leaf margin
a. entire
b. toothed
c. half entire, half toothed

22. leaf margin indumentum
a. glabrous
b. hairy

23. leaf apex
a. acute (length $<1.5$ times width)
b. acuminate (length at least 1.5 times width)

24. leaf texture
a. rugose
b. not rugose

25. veins number (pairs: non-overlap)
a. less than 9
b. more than 9

The number of veins in the wider part of the lamina is used when the number of veins on each side of the central axis is unequal. Therefore, the number of veins is not always in pairs.

26. venation arrangement
a. pinnate
b. actinodromous
c. acrodromous

27. venation symmetry - basal secondary veins
a. both directed towards apex (or almost so)
b. both directed towards margin (or almost so)
c. one towards apex or almost so, the other towards margin or almost so

28. veins - basal secondary pair origin
a. arises at base of primary vein (or arising at a point $<2 \mathrm{~mm}$ above base)
b. arises above base of primary vein (at least $2 \mathrm{~mm}$ above base)

29. veins - basal secondary pair distance

a. basal pair of secondary veins arise together from same position or within $2 \mathrm{~mm}$ of each other

b. basal pair of secondary veins arise from different positions, at least more than $2 \mathrm{~mm}$ apart

30. veins - secondary arrangement
a. joined to next distal secondary vein
b. directed to margin or almost so, not joined up to next secondary vein
c. some secondary veins directed to margin, others joining up to next secondary vein

31. leaf cystolith shape
a. punctiform
b. linear

32. leaf abaxial cystoliths venation
a. absent (cystoliths not arranged on veins of abaxial surface)
b. on primary and secondary veins (cystoliths present on primary and secondary veins of abaxial surface)

33. leaf abaxial cystoliths interstices

a. absent (cystoliths not present on interstices of abaxial surface)

b. on interstices (cystoliths present on interstices of abaxial surface)

34. leaf adaxial cystoliths venation
a. absent (cystoliths not arranged on veins of adaxial surface)

b. present (cystoliths present on veins of adaxial surface)

35. leaf adaxial cystoliths interstices

a. absent (cystoliths not present on interstices of adaxial surface)

b. present (cystoliths present on interstices of adaxial surface)

36. leaf abaxial indumentum venation

a. absent (hairs absent from veins of abaxial surface)

b. on primary, secondary and tertiary veins

37. leaf abaxial indumentum interstices
a. absent (hairs absent from interstices of abaxial surface)
b. on interstices 
Table 2 (cont.)

38. leaf adaxial indumentum venation

a. absent (hairs absent from veins of adaxial surface)

b. on primary, secondary and tertiary veins

39. leaf adaxial indumentum interstices

a. absent (hairs absent from interstices of adaxial surface)

b. on interstices

40. nanophyll (small leaves)
a. absent

b. present

41. flower sexuality

a. unisexual

b. bisexual

42. male inflorescence

a. sessile (or subsessile)

b. pedunculate (distinctly so)

43. male inflorescence density

a. condensed/crowded (male flowers crowded together)

b. open (male flowers spaced from each other)

44. male inflorescence branching
a. branched
b. unbranched

45. male inflorescence type
a. head-like
b. discoid
c. paniculate
d. racemose
e. spike-like

46. male inflorescence involucral bracts
a. absent
b. present

47. male inflorescence bracts appendage
a. absent
b. present

48. male inflorescence bract margin (when bracts present)
a. glabrous

b. hairy

49. male inflorescence orde

a. unordered

b. distinctly ordered into compartments

50. male flower symmetry

a. actinomorphic

b. zygomorphic

51. male flower tepal length (non-overlap)
a. less than $1.8 \mathrm{~mm}$
b. more than $1.8 \mathrm{~mm}$

52. male flower tepal number
a. one
b. two
c. three
d. four
e. five

53. male flower tepal fusion

a. free (tepals not joined to each other)

b. connate (at least connate on basal half)

54. male flower tepal appendage
a. absent (or present as a slightly raised bump)
b. short (less than 0.25 times length of tepal)
c. long (0.25-0.5 times length of tepal)
d. very long (more than 0.5 times length of tepal)

55. male flower tepal indumentum
a. glabrous
b. hairy

56. male flower stamen number
a. one
b. two
c. three
d. four
e. five

57. male flower staminal inflection in bud
a. inflexed
b. erect

58. male flower rudimentary ovary
a. absent
b. present

59. female inflorescence
a. sessile
b. pedunculate

60. female inflorescence branching
a. unbranched
b. branched

61. female inflorescence arrangement
a. open (female flowers spaced from each other)
b. condensed, crowded (female flowers crowded together)

62. female inflorescence type
a. head-like
b. discoid
c. paniculate
d. racemose
e. spike-like

63. female inflorescence involucral bracts
a. absent
b. present

64. female inflorescence bracts appendage (when bracts present)
a. absent
b. present

65. female flower bract margin (when bracts present)
a. absent
b. present

66. female flower symmetry

a. actinomorphic (or slightly asymmetrical)

b. zygomorphic

67. female flower tepal number
a. zero (tepals absent or tepals minute and so not readily visible)
b. one
c. two
d. three
e. four
f. five
g. six

68. female flower tepal comparative size
a. equal

b. unequal

69. female flower tepal fusion
a. free
b. connate (at least connate in part)

70. female flower staminode presence
a. absent
b. present

71. female flower staminode inflection in bud (when staminodes present)
a. inflexed

b. erect

72. female flower ovary
a. straight
b. oblique

73. female flower style
a. absent
b. present

74. female flower stigma
a. capitate
b. penicillate
c. peltate
d. oblong, filiform to linear

75. achene covered by perianth or involucre
a. not enclosed (or only partly so)
b. enclosed (or almost completely so)

76. achene surface
a. smooth
b. ribbed
c. dimpled 
characters were a posteriori re-weighted according to their RC and, for comparison, their $\mathrm{Cl}-\mathrm{u}$ values, such that those characters with a higher 'parsimony fit' to a tree received a higher weighting than those with lower values. Subsequent analyses using $\mathrm{Cl}-\mathrm{u}$ and $\mathrm{RC}$-weighted characters were conducted with branch-swapping limited to a maximum of 200 trees per replicate and 100 random taxon addition to search for multiple islands of most-parsimonious (MP) trees.

\section{Phenetic analysis}

Construction of a distance tree using clustering was calculated using the Unweighted Pair Group Method with Arithmetic Mean (UPGMA), producing a tree reflecting the phenotypic similarities between taxa.

\section{RESULTS}

The data matrix comprised 76 characters (Table 2) and 55 taxa (Table 3). Analysis using unweighted characters resulted in 13198 most parsimonious (MP) trees of 390 steps $(\mathrm{Cl}-\mathrm{u}=$ $0.23, \mathrm{RI}=0.63, \mathrm{RC}=0.14$ ).

The strict consensus tree (Fig. 3 ) is characterised by a large polytomy containing all members but one of the tribe Elatostemeae, with considerable character support (decay +3 ). Pilea nummulariifolia is placed as sister to the remaining taxa in the tribe (decay +2$)$. This refutes the monophyly of Pilea, since P. microphylla is closer to members of Elatostema and Procris than it is to $P$. nummulariifolia. Neither of the other two genera appears monophyletic, although the analysis does not refute monophyly in either case. However, apart from $P$. reticulatovenosa, the remainder of Procris spp. are placed within a clade (P1; decay +1 ) indicating they are more closely related to each other than to Elatostema. There are two other clades of Elatostema species: i) clade E1 contains seven species from the Mt Kinabalu area of Sabah and receives some support (decay +2$)$; ii) clade E2 that includes E. latifolium and E. tsoongii (decays +1 ). Relationships between these three clades and the remaining members of the tribe are unresolved. Hence there is no support from the morphological database for any of the generic groupings within Elatostemeae. Pilea appears polyphyletic, but this estimate of relationships does not refute the monophyly of either Elatostema or Procris.

Within the non-Elatostemeae taxa, Dendrocnide sinuata and $D$. stimulans form a strongly supported clade (decay +7$)$ with Urtica dioica sister to these two species (decay +1). Myriocarpa longipes (Boehmerieae) is sister to this latter clade, rather

Table 3 Morphological data matrix of 55 species and 76 characters (as listed in Table 2); '?' represents inapplicable characters or characters not available from specimens used; character state values in parentheses represent multiple character state scores.

\begin{tabular}{|c|c|c|c|c|c|c|c|c|}
\hline Boehmeria calophleba & $110000000 ?$ & ?211010110 & 1101020000 & 0000111010 & 0????????? & ?????????? & ?????????? & ?????? \\
\hline B. microphylla & 1100000010 & 1010010110 & $11110200 ? 0$ & 0000111010 & $0101400 ? 00$ & ?(23)10?(23)1110 & $1400 ? 02010$ & $? 11312$ \\
\hline Dendrocnide sinuata & $220000100 ?$ & ?212011010 & $10 ? 1101000$ & 0111111110 & 011020???0 & 03001311?? & ?????????? & ?????? \\
\hline D. stimulans & $220000100 ?$ & ?202011110 & 0011101101 & 0111110110 & 011020???0 & $030013010 ?$ & $? 20 ? ? 04000$ & $? 00300$ \\
\hline Elatostema acuminatum & $000000000 ?$ & $? 0000(01) 0111$ & 0011011000 & 1000100001 & 0001110000 & $0(34) 100(34) 010 ?$ & ?010103101 & $? 00302$ \\
\hline E. auriculatifolium & 0100000010 & $100001010 ?$ & $101102(02) 012$ & 1110000001 & 011011???0 & $040 ? 040 ? 00$ & $100(34) 0010 ? ?$ & ??111? \\
\hline E. backeri & 0010000010 & 10??0??(01)01 & $1111 ? 11010$ & 1010111010 & 0001011100 & ?(34)110(34)010? & ?111100101 & ?00301 \\
\hline E. bullatum & $00(01) 0000000$ & 1010010101 & 11(01)0?????? & 1111110111 & 011011??10 & $0300030 ? 01$ & $011 ? 003(01) 01$ & 0????1 \\
\hline E. curtisii & $00 ? 000000 ?$ & $? 000010(01) 11$ & 2011001111 & $? 110100000$ & $000100 ? ? 00$ & $141304010 ?$ & $? 00 ? ? 05010$ & $? 00310$ \\
\hline E. dallasense & $0(01) 001000 ? 0$ & 1000010101 & 1111?????? & 1111111111 & 011011??:10 & $030 ? 130 ? 01$ & $011 ? ? 03101$ & $0 ? ? ? ? 0$ \\
\hline E. grande & $000000000 ?$ & $? 000010101$ & 1111001111 & 1111111100 & 0101110100 & $131 ? 13010 ?$ & ?110100??1 & ?00301 \\
\hline E. griffithianum & 0000000010 & 1010010101 & 1011011110 & 1000110000 & 0110201100 & $040314010 ?$ & ?000105111 & ?00302 \\
\hline E. heyneanum & 0000000010 & $10 ? 0000011$ & ??11012002 & 1111100001 & $01 ? 1 ? 00000$ & $0410140 ? 1 ?$ & ??000????1 & $? 00 ? 12$ \\
\hline E. integrifolium & $0(01) 0000000 ?$ & $? 000010111$ & 0011011110 & 1111100100 & 0001010110 & 0?????0??? & ?????????? & ?????? \\
\hline E. kinabaluense & $001000000 ?$ & $? 0000001 ? 1$ & 1101011011 & 1111110000 & 0????????? & ?????????? & ?????????? & ?????? \\
\hline E. latifolium & 0000000010 & 101(12)01(01)111 & 0011012102 & 1101110000 & $01 ? 1 ? 00 ? 00$ & 0310?30?1? & ??00?04001 & $? 00 ? 02$ \\
\hline E. lineolatum & $000000000 ?$ & $? 000000111$ & 1011012010 & 1101110000 & $000100 ? ? 00$ & $0(34) 100(34) 0 ? 0 ?$ & ?????????? & ?????? \\
\hline E. macrophyllum & $0(01) 0000000 ?$ & ?011011101 & $1111(01) 01110$ & 1111111010 & 0001110110 & 03000301?? & ?????????? & ?????? \\
\hline E. manillense & $000000000 ?$ & ?01(01)01(01)111 & $? 011012111$ & 1101100000 & $011020 ? ? 00$ & $0(34) 120(34) 0 ? 0 ?$ & $? 00 ? 10 ? 001$ & $? 00 ? 02$ \\
\hline E. maraiparaiense & $01111000 ? 0$ & $10100101(01) 1$ & $21(01) 1001112$ & ?0011(01)1??1 & 0?1011???0 & $0(34) 0 ? 1(34) 0 ?(01) 1$ & 011??0(345)101 & 0????? \\
\hline E. papillosum & $0 ? 00000010$ & $10000101 ? 1$ & 1111012010 & 1100011111 & 0101110010 & 0?????????? & ?1101????1 & $? 00 ? 02$ \\
\hline E. parvum & 0010000010 & $1000000(01) 01$ & 1111011110 & 1110110011 & 0001010100 & $041114010 ?$ & ?111100101 & ?00301 \\
\hline E. pedunculosum & $000000000 ?$ & 1000010(01)01 & 1011022110 & 1000111010 & 0101011000 & $131 ? 0301 ? ?$ & ?????????? & ?????? \\
\hline E. pinnativenium & $0(01) 00(01) 000 ? 0$ & $101001010(01)$ & (01)101?0???? & $111(01)(01) 11111$ & 001001??10 & $030 ? 130 ? 01$ & 0?1??03(01)01 & 0????1 \\
\hline E. purpurascens & $00000000 ? 0$ & 1010000101 & 11(01)1?????? & 1111110111 & 011001???0 & $0301 ? 30 ? 01$ & 011??03001 & 0????1 \\
\hline E. repens & 0010000010 & 1000010111 & 0001010110 & 1000111000 & $011020 ? ? 00$ & $14100401 ? ?$ & ?????????? & ?????? \\
\hline E. reticulatum & $0(01) 0000000 ?$ & $? 000010101$ & 1111101111 & 1101111000 & 0101111100 & (01)41114010? & ?111100??1 & $? 00300$ \\
\hline E. rostratum & $0(01) 0000000 ?$ & $? 000010111$ & 2111011110 & 1111111110 & 0001011100 & $041214010 ?$ & $? 111100101$ & $? 00301$ \\
\hline E. serpentinicola & $00001000 ? 0$ & $10000(01) 0101$ & 1?(01)1?????? & $111111(01) 111$ & 011011???0 & $030 ? 031 ? 01$ & 0111?0(34)001 & $0 ? ? ? ? 1$ \\
\hline E. sessile & $000000000 ?$ & $? 000010111$ & 1111011110 & 1011111010 & 0????????? & ?????????? & ?????????? & ?????? \\
\hline E. sinuatum & $000000000 ?$ & $? 00001(01) 1 ? 1$ & 2011001111 & 1010100001 & 0????????? & ????????0? & $? 00 ? 005001$ & $? 00 ? 10$ \\
\hline E. stipitatum & 0010000010 & $1000010(01) 01$ & 1101011111 & 1101111010 & 0101011100 & $031213011 ?$ & ?111100?01 & $? 00300$ \\
\hline E. strigosum & $000000000 ?$ & $? 0000101 ? 1$ & 1111011110 & 1010111010 & 0001111100 & $(01)(34) 121(34) 010 ?$ & $? 111100101$ & $? 00301$ \\
\hline E. tsoongii & 0000000010 & 1012010111 & $00010120 ? 2$ & 1101110000 & 0????????? & ????????1? & ?30???4??1 & $? 00 ? 0 ?$ \\
\hline E. urvilleanum & 0010000000 & 100000(01)101 & 2011011110 & 1010100010 & 0001011110 & $031203010 ?$ & ?111100??1 & $? 00301$ \\
\hline E. velutinicaule & 0010000000 & $12000001 ? 1$ & 1001001011 & 1010111010 & 0001001100 & $131213010 ?$ & $? 001100 ? ? 1$ & ?0030? \\
\hline Elatostema sp.A399068 & 0000000010 & 1000000001 & 1000011000 & 1010000010 & 0????????? & ????????0? & $? 111000 ? ? 1$ & $? 00301$ \\
\hline Myriocarpa longipes & $210000000 ?$ & ?212011010 & $11 ? 1001001$ & 1000111010 & $01 ? 1400100$ & 03?01301?? & ?????????? & ?????? \\
\hline Parietaria judaica & $000000000 ?$ & ?211000(01)10 & 0111021111 & 0000111010 & 0001000100 & (01)31013010? & ?000104010 & $? 00 ? 10$ \\
\hline Pr. archboldiana & $000 ? 100000$ & 1110010101 & (01)001001100 & 1011100001 & $01102 ? 0000$ & $0400 ? 40111$ & 000000???1 & 000010 \\
\hline Pr. frutescens & 0001000000 & 1110010111 & $1110(01) 01101$ & 1111100001 & 0110200000 & 0(34)000(34)0101 & $00000050 ? 0$ & 000012 \\
\hline Pr. goepeliana & (01)000000000 & $101(01) 010111$ & 0001001000 & 1010100001 & 0110200000 & 0400040111 & 001??????? & ?????? \\
\hline Pr. insularis & $000000000 ?$ & $? 010010111$ & 001100110(01) & 1111100001 & 011020???0 & 1410040001 & $00 ? 000 ? 0 ? 1$ & 000010 \\
\hline Pr. pedunculata & 0(01)01000000 & 1110010111 & $001 ? 001111$ & 1111100001 & 0110200000 & 1400040101 & 100?00???0 & $? 00010$ \\
\hline Pr. reticulatovenosa & 1001000000 & 1100010111 & $201 ? 0011 ? 1$ & 1110000001 & 0????????? & ????????0? & ?0???????? & ?????? \\
\hline Pr. ruhlandii & $0(01) 01000000$ & 1110010111 & $00110011 ? 1$ & 1111100000 & 01102????? & ????????0? & ?0???????? & ?????? \\
\hline Pr. urdanetensis & 0101000000 & 1110000111 & $201 ? 0011 ? 1$ & 1111100000 & 01102????? & ????????0? & ?0???????? & ?????? \\
\hline Pr. wightiana & $?(01) ? ? ? 00001$ & $? 110010111$ & 1???00???? & $111110000 ?$ & 01???????? & ????????1? & ?????????0 & ?0???? \\
\hline Urtica dioica & $0(01) 0000100 ?$ & ?1110(01)0010 & $11000110 ? 1$ & 0001111010 & 011020???0 & $031013011 ?$ & $? 20 ? ? 04100$ & $? 00010$ \\
\hline U. urens & $000000100 ?$ & ?01(01)000010 & 1101020001 & 0000111010 & 0001000100 & (01)310130?01 & 1000104100 & $? 00310$ \\
\hline
\end{tabular}




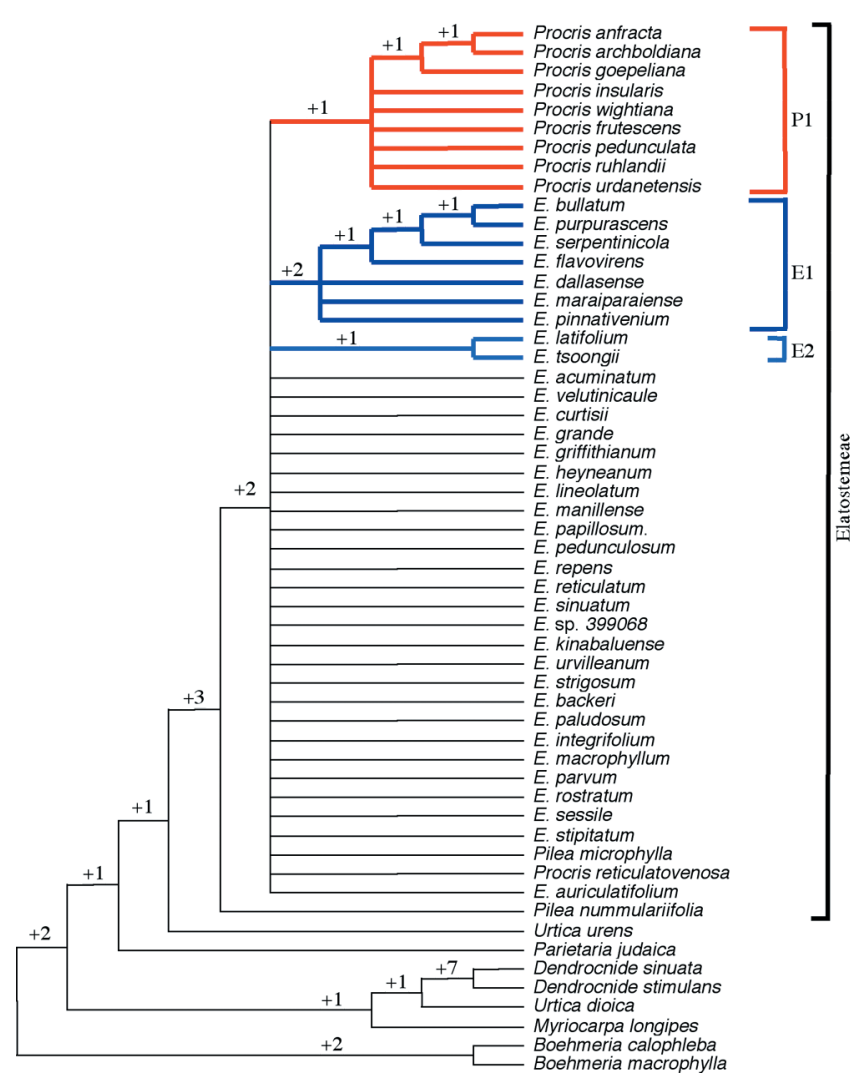

Fig. 3 Strict consensus tree obtained from a heuristic search with 1000 replicates of the equally weighted morphological dataset; tree length $=390$ steps; $\mathrm{RI}=0.63 ; \mathrm{RC}=0.14$ coloured lines indicate the clades referred to in text: blue lines = Elatostema bullatum clade $(\mathrm{E} 1)$, pale blue lines $=E$. latifolium - E. tsoongii clade (E2), red lines = Procris p.p. maj. clade (P1). Decay values are cited above the lines.

than being placed with the two species of Boehmeria. Tribe Urticeae appears polyphyletic because Urtica urens is placed closer to Elatostemeae than to the Dendrocnide-Urtica dioica clade. Parietaria judaica (Parietarieae) is sister to the Urtica urens-Elatostemeae clade (decay +1$)$.

Since the strict consensus tree was poorly resolved, the majority rule tree (Fig. 4) was considered because it may provide additional information on potential relationships. Procris reticulatovenosa is placed sister to all other Procris spp. (clade P1) in $55 \%$ of trees, suggesting that Procris may be monophyletic. Elatostema curtisii and $E$. sinuatum are grouped together with all Procris species (in $94 \%$ of the trees) forming a clade P2. There is a suggestion (in $80 \%$ of the trees) that clade P2 and several other members of Elatostema, namely members of subg. Pellionia, E. manillense (subg. Elatostematoides) and E. auriculatifolium (either a member of subg. Elatostema or subg. Pellionia), plus Pilea microphylla, are closely related to each other and forming a clade (P3).

Within Elatostema species, E. macrophyllum and E. paludosum (both subg. Elatostema) group together in $62 \%$ of the trees (clade E3), with this clade sister to several other members of subg. Elatostema (clade E1) in $62 \%$ of the trees. Clade E4, comprising members of subgenera Elatostema, Elatostematoides and Weddellia (in $57 \%$ of the trees), and E. acuminatum and $E$. integrifolium occur together in $74 \%$ of the MP trees (clade E5).

The UPGMA dendrogram (Fig. 5) recognises two major morphological groups (A and B) and several minor ones. Group D1 comprises all the species grouped in clade E3 (Fig. 4) plus five other species that are unresolved in Fig. 4. Group D2 consists of the clade E1 (Fig. 3, 4), E3 (Fig. 4), and E. papillosum. Group B

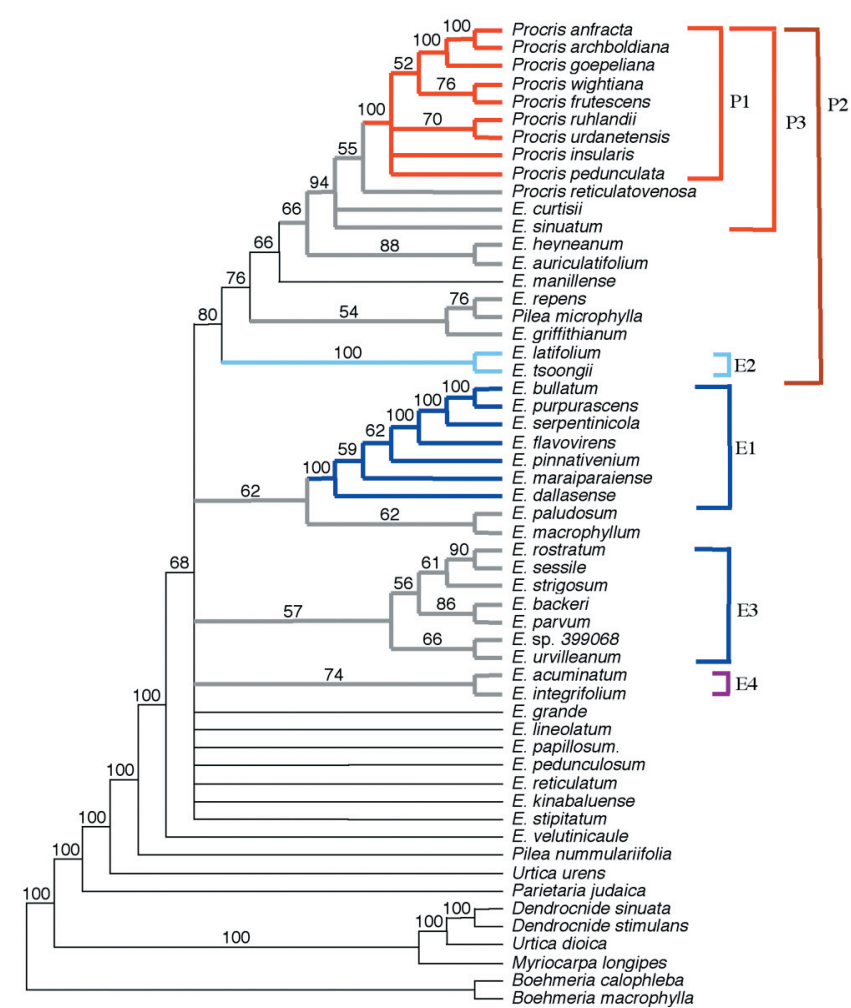

Fig. 4 Majority rule tree, equally weighted morphological dataset; percentage of MP trees supporting each node is given above the line; grey lines = new clades formed on this cladogram that were not resolved on strict consensus tree (Fig. 3); other coloured lines refer to clades recognised in strict consensus tree (refer Fig. 3 for explanation).

shows a close similarity to clade P3 (Fig. 4), containing all the taxa in the latter, plus clade E5 (Fig. 4) and two additional species, E. kinabaluense and E. lineolatum.

Pilea nummulariifolia clusters with species of the Boehmerieae, Urtica and Parietaria judaica. Species of Urtica are clustered with Parietaria judaica rather than with species of Dendrocnide. Myriocarpa longipes is clustered with species of Boehmeria rather than with Dendrocnide-Urtica dioica (Urticeae) as suggested by the parsimony analysis (Fig. 3). Hence the UPGMA analysis supports the current circumscription of Boehmerieae (based on species included in this study), but does not support the Urticeae.

Analysis of $\mathrm{Cl}-\mathrm{u}$ weighted data found 16 trees $(\mathrm{RI}=0.69, \mathrm{RC}=$ 0.22). The strict consensus tree of these (Fig. 6) shows much better resolution of relationships between species than the equally weighted one. It contains a number of clades that are similar to groups in the UPGMA analysis. Within the Elatostemeae there are two main clades labelled A and B (Fig. $6)$. Within clade $A$ there are two terminal subclades that are similar to group A of the UPGMA analysis (Fig. 5), namely E1* and $E 4^{*}$. The topology and composition of the upper subclade $\left(E 4^{*}\right)$ is similar to group D1 (Fig. 5) and also to clade E4 (Fig. 4) (containing all members of the latter plus three additional species, E. pedunculosum, E. reticulatum and E. stipitatum). The lower subclade $\left(E 1^{*}\right)$ comprises clade $E 1$ (as resolved in Fig. 3) plus E. macrophyllum, and also with some species common with that of group D2 (Fig. 5). Likewise, the species composition of clade B (Fig. 6) is similar to clade B (Fig. 5), as well as to some elements in Fig. 3 and 4. All species of Procris are grouped within the terminal polytomy $\left(\mathrm{P} 1^{*}\right)$ of clade $\mathrm{B}$ (Fig. 6), with Procris reticulatovenosa nested among members of Procris pro parte majore clade (P1 of Fig. 3), and E. curtisii-E. sinuatum clade sister to this (also refer Fig. 4, 5). All the remaining eight taxa that attach to the base of the Procris 


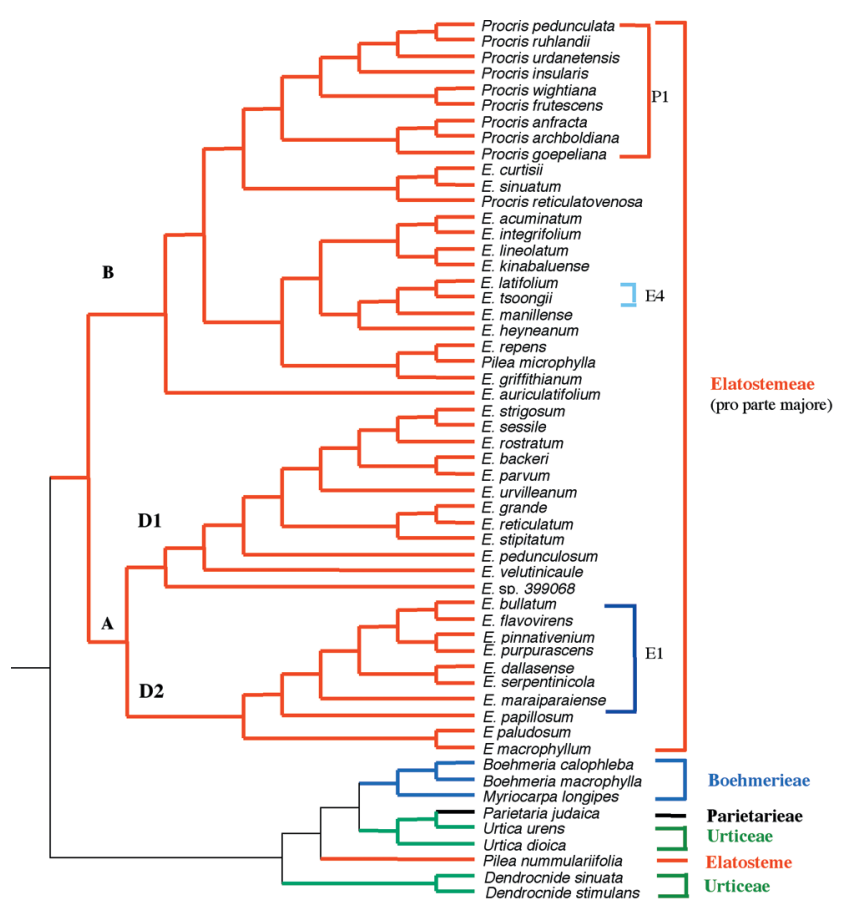

Fig. 5 UPGMA tree of equally weighted morphological dataset (refer Fig. 3 for further details); coloured lines and text are used to make it easier to distinguish the tribal groupings sensu Gaudichaud (1830) and Friis (1993). A, B, D1 and D2 = clades as referred to in text.

clade in Fig. 4, and are also placed within clade B (Fig. 5), are attached at the base of clade B in Fig. 6 . Hence, there is considerable similarity in the estimates of relationships and degree of similarity within the ingroup taxa from all three methods of analysis. Tribe Urticeae is polyphyletic in the $\mathrm{Cl}-\mathrm{u}$ weighted analysis, with Urtica urens placed outside the Urticeae clade and closer to Elatostemeae, as also shown in the parsimony analysis of the equally weighted dataset (Fig. 3, 4). However, Myriocarpa longipes (Boehmerieae) is nested within the main Urticeae clade (Fig. 6), or is placed sister to the main Urticeae clade (Fig. 3, 4). Hence neither analysis provides support for the inclusion of Myriocarpa longipes within Boehmerieae. Analysis of RC-weighted data (not presented here) found 71 trees of 60.80 steps $(R I=0.75, R C=0.27)$. The topology of the strict consensus tree of the RC-weighted data was topologically similar to the $\mathrm{Cl}-\mathrm{u}$ weighted strict consensus tree.

\section{DISCUSSION}

The low level of decay support for the clades within the equally weighted strict consensus tree indicates the weakness of the traditionally used morphological characters for indicating evolutionary affinities (Fig. 3). Even though there are several robustly supported clades in the strict consensus trees from the equally and $\mathrm{Cl}$-u weighted characters (Fig. 3 and 6, respectively), the $\mathrm{RC}$-weighted tree (not presented here) and in the majority rule tree from the equally weighted analysis (Fig. 4), most of these branches are only supported by one or two character changes as shown in the phylogram of one of the MP trees from the equally weighted analysis (Fig. 7).

\section{Evaluation of the subgeneric classification of Schröter \& Winkler}

The previous subgeneric classification of Schröter \& Winkler $(1935,1936)$ is mapped onto the strict consensus trees of equally weighted (Fig. 8) and the Cl-u weighted morphological analyses (Fig. 9). The following species, E. auriculatifolium, E. bullatum, E. dallasense, E. flavovirens, E. maraiparaiense, E. pinna-

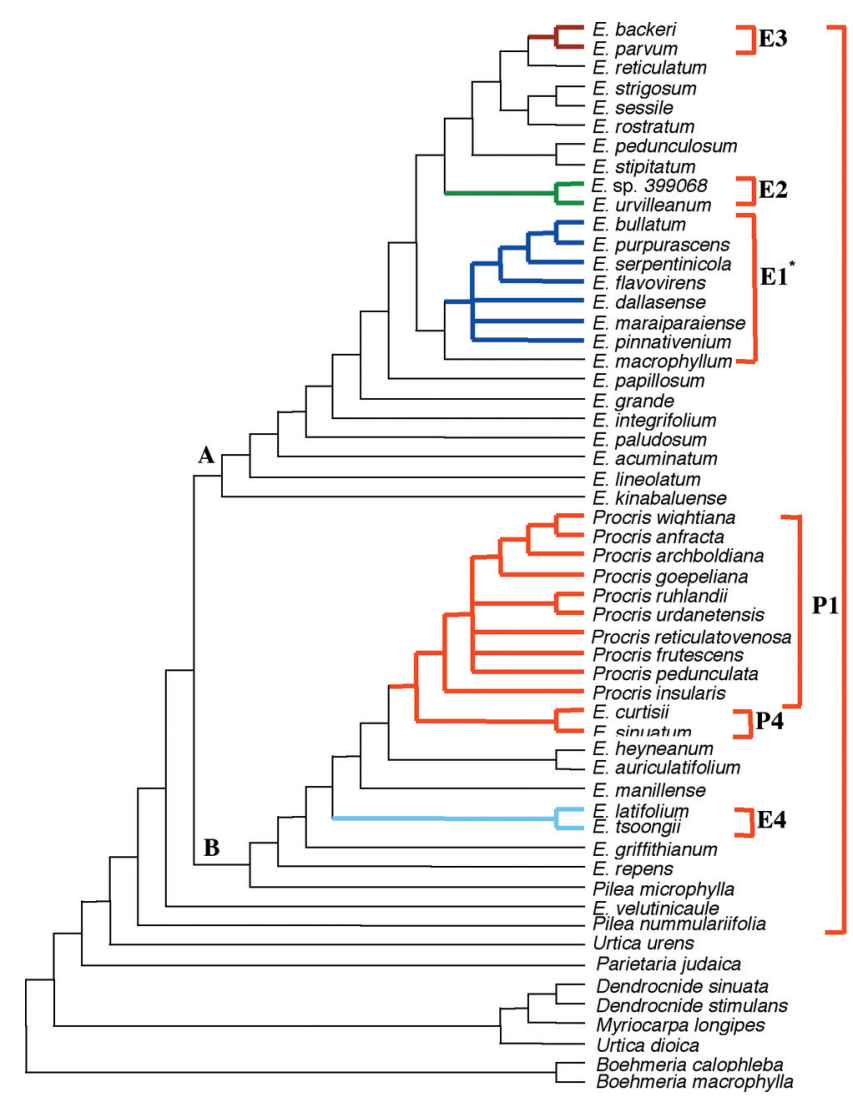

Fig. 6 Strict consensus of 16 MP trees obtained from heuristic searching of the $\mathrm{Cl}$ weighted morphological dataset; tree length $=89 ; \mathrm{RI}=0.69 ; \mathrm{RC}=$ 0.22 ; coloured lines indicate clades that are also formed on the strict consensus of the equally weighted data (Fig. 3); labelled clades as referred to in the text.

tivenium, E. purpurascens and E. serpentinicola have been here assigned to subgenera based on an examination of descriptions (Beaman \& Cellinese 2004) and photographs of herbarium specimens (held at L) determined by R.S. Beaman. However, the subgeneric position of $E$. auriculatifolium is unclear because although the description suggests that this species may be a member of subg. Elatostema, based on the photograph of J. \& M.S. Clemens 50984, (L565832 - possibly with male flowers) this species could belong to either subg. Elatostema or subg. Pellionia. Procris, recognised as a distinct genus by Schröter \& Winkler $(1935,1936)$, has been included here for comparison. The lack of resolution in the equally weighted analysis means that there is little information relevant to the subgeneric concepts. All but one representative of Procris are grouped in clade P1, but the representatives of subg. Elatostema, Elatostematoides, Pellionia and Weddellia are placed within the large polytomy. Hence the analysis neither supports nor refutes Schröter \& Winkler's groupings. Comparison of the subgeneric classification with the re-weighted analysis is more fruitful (Fig. 9). All representatives of Procris are placed within clade $\mathrm{P} 1^{*}$, and all representatives of subg. Pellionia attach as a grade below $\mathrm{P} 1^{*}$ within clade $\mathrm{B}$, along with $E$. manillense (subg. Elatostematoides). Therefore, these data support the strong affinities of subg. Pellionia and Procris. Furthermore, these morphological data support the reduction of Procris to an infra-generic level within Elatostema as suggested by Hallier (1896). The two representatives of subg. Elatostematoides are widely separated within both clade $\mathrm{A}$ (E. rostratum) and clade $B$ ( $E$. manillense); there is no evidence of them being close relatives. The three species of subg. Weddellia (E. backeri, E. parvum and E. papillosum) are placed within clade A, but only two of these species (E. backeri and E. parvum) are grouped 


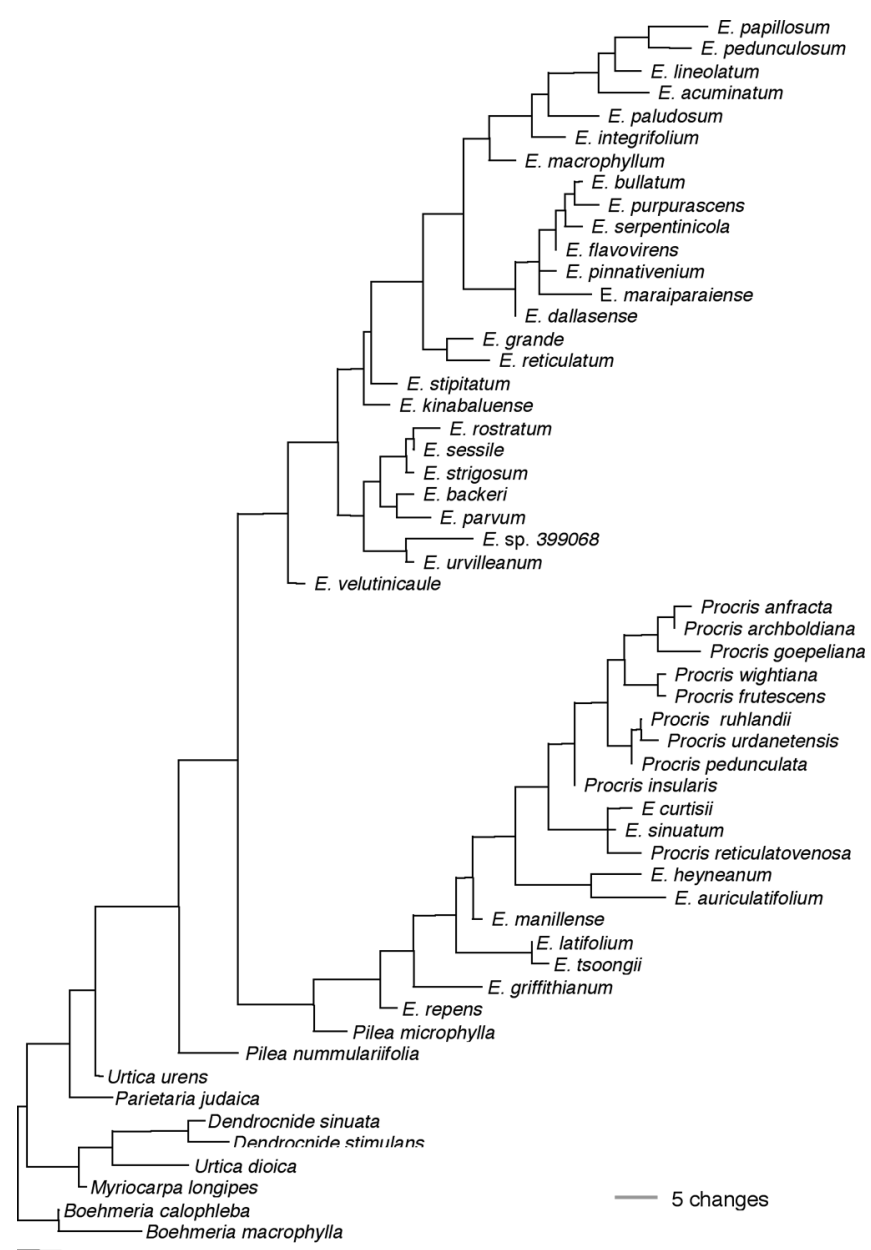

Fig. 7 Phylogram (branch lengths proportional to amount of change) of one of the MP trees found from the parsimony analysis of the equally weighted morphological dataset.

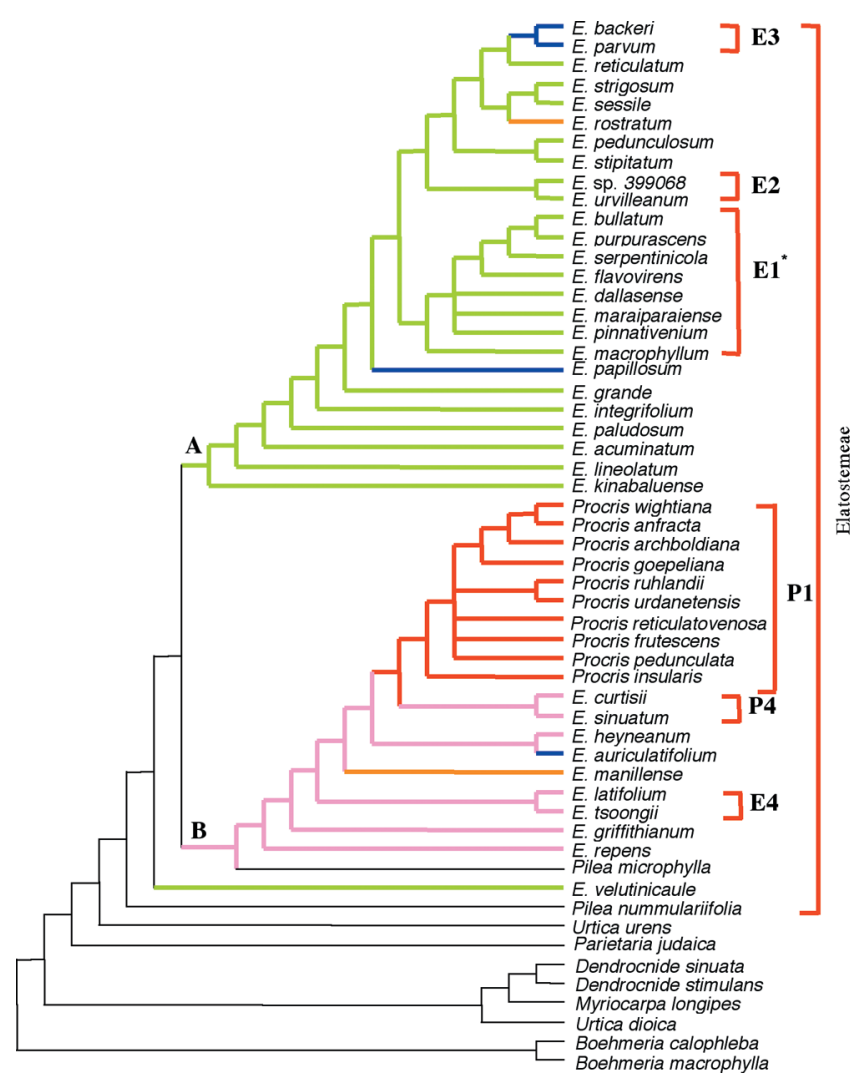

Fig. 9 Subgeneric classification (sensu Schröter \& Winkler 1935, 1936) mapped on the strict consensus tree of $\mathrm{Cl}$ weighted morphological dataset. Details of coloured lines are given in Fig. 8.

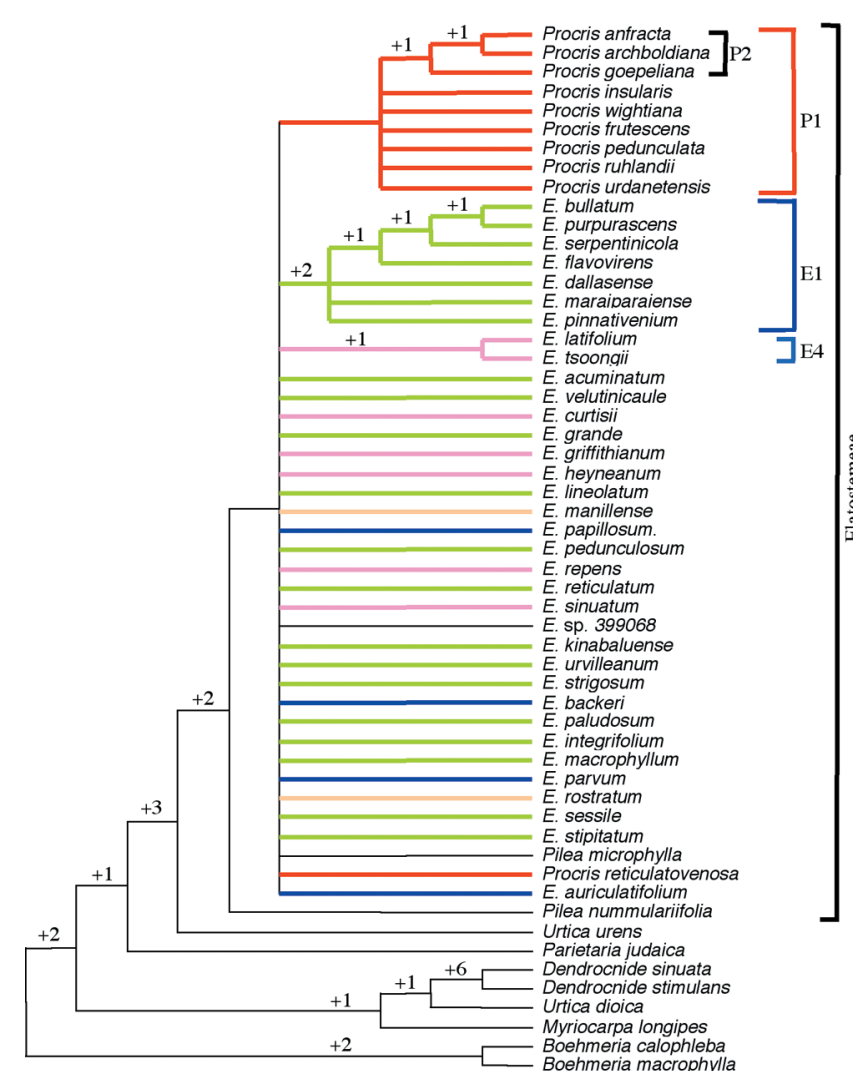

Fig. 8 Subgeneric classification (Schröter \& Winkler 1935, 1936) mapped on the strict consensus tree of equally weighted morphological dataset. Pink lines $=$ subg. Pellionia; gold lines $=$ subg. Elatostematoides; blue lines $=$ subg . Weddellia; green lines = subg. Elatostema; narrow black line = not assigned to subgenus; red lines = a currently separated genus Procris. Decay values are cited above lines.

together, and these appear to be more closely related to species of subg. Elatostema than to the other species of subg. Weddellia. All members of subg. Elatostema are placed within clade $A$, except $E$. velutinicaule, which is placed at the base of the Elatostemeae-clade.

The inclusion of Pilea microphylla within the representatives of Elatostema in all analyses of the morphological data (Fig. 3-9) does not support the monophyly of Pilea. However, a larger sample of species of Pilea and an expanded characterset are required before the phylogeny of this genus could be resolved.

\section{CONCLUSION}

Parsimony analysis of the equally weighted morphological dataset provided very little resolution of relationships within Elatostema-Procris. The fit of the data to the resultant MP trees was very low $(R C=0.14)$, indicating a very high level of homoplasy in many characters. Parsimony analysis with reweighted characters greatly improved the resolution (Fig. 6). We conclude that the groupings obtained from the $\mathrm{Cl}-\mathrm{u}$ and $\mathrm{RC}$ weighted parsimony analyses indicate the existence of some phylogenetic signal in these data, although this is weak and mostly obscured in the equally weighted parsimony analysis.

Based on the analyses of these morphological data, there is no support for the subgeneric classification of Elatostema by Schröter \& Winkler (1935). The more recent infrageneric classification of Elatostema by Wang (1980a) into sections and series, has not been considered here. However, since Wang (1980a) more or less maintained the same taxonomic concepts as Schröter \& Winkler's infrageneric classification, but 
regarded their subgenera as sections, there is no support for his sect. Elatostema or sect. Weddellia. Since the monophyly of Elatostema subg. Pellionia is not supported in our analyses, the recognition of this taxon, but as the distinct genus Pellionia (Wang 1980b), is also not supported by the morphological data used here. Therefore, at least in part, there is no support for the sectional and generic classification of these above taxa as defined by Wang (1980a, b). Furthermore, based on the morphological characters analysed here, the taxonomic status of Pilea and Procris requires further review. A re-assessment of morphological characters and consideration of additional morphological features would be useful. It is recommended that the usefulness of morphological characters in evaluating the phylogeny of infra-generic taxa of Elatostema, together with those of other Elatostemeae, would greatly benefit from being considered within a molecular framework based on analyses of molecular data. Since greater homoplasy is often found in morphological data (Givnish \& Sytsma 1997a), morphological data may be misleading compared to the large statistical advantage of molecular data (Givnish \& Sytsma 1997b). Studies based on molecular data are more likely than morphological studies to provide accurate insights into phylogenetic relationships.

\section{REFERENCES}

Almeida MT, Bisby FA. 1984. A simple method for establishing taxonomic characters from measurement data. Taxon 33: 405-409.

Ariyanti EE. 2004. Systematic studies of Procris (Urticaceae). Unpublished MSc thesis, University of Sydney, Australia.

Ariyanti EE, Conn BJ. 2005. Phylogeny of Procris (Urticaceae) using gapweighting techniques. In: Tuen AA, Das I (eds), Wallace Sarawak - 150 years later: 106-122. Institute of Biodiversity and Environmental Conservation, Universiti Malaysia Sarawak, Kuching.

Beaman RS, Cellinese N. 2004. Eight new species and a new name in the genus Elatostema (Urticaceae) on Mount Kinabalu, Sabah, Malaysia. Blumea 49: 135-144.

Bernbeck F. 1932. Vergleichende Morphologie der Urticaceen- und Moraceen-infloreszenzen. Botanische Abhandlungen 19: 1-100.

Bigalke H. 1933. Die blattspodogramme der Urticaceae und ihre verwendbarkeit für die systematik. Beiträge zur Biologie der Pflanzen 21: 1-58.

Chappill JA. 1989. Quantitative characters in phylogenetic analysis. Cladistics 5: 217-234.

Dengler NG. 1999. Anisophylly and dorsiventral shoot symmetry. International Journal of Plant Sciences 160 (6 Supplement): S67-S80.

Forey PL, Humphries CJ, Kitching IJ, Scotland RW, Siebert DJ. 1992. Cladistics: A practical course in systematics. Clarendon Press, Oxford.

Friis I. 1993. Urticaceae. In: Kubitzki K, Rohwer JG, Bittrich V (eds), The families and genera of vascular plants II, flowering plants - dicotyledones. Magnoliid, hamamelid and caryophyllid families: 612-630. Springer-Verlag, Berlin.

Givnish TJ, Sytsma KJ. 1997a. Homoplasy in molecular vs. morphological data: the likelihood of correct phylogenetic inference. In: Givnish TJ, Sytsma KJ (eds), Molecular Evolution and Adaptive Radiation: 55-110. Cambridge University Press, New York.
Givnish TJ, Sytsma KJ. 1997b. Consistency, characters, and the likelihood of correct phylogenetic inference. Molecular Phylogenetics and Evolution 7: $320-330$.

Goebel K. 1928. Organographie der Pflanzen insbesondere der Archegoniaten und Samenpflanzen, edition 3, umgearb. Aufl., I: Allgemeine Organographie. Fischer, Jena.

Golenkin M. 1894. Beitrag zur Entwicklungsgeschichte der Infloreszenzen der Urticaceen und Moraceen. Flora 78: 97-132.

Hagedorn G. 2005. DeltaAccess a SQL interface to DELTA, the Description Language for Taxonomy, implemented in Microsoft Access 97, 2000, and 2002 (=XP) (http://www.diversityworkbench.net/OldModels/Descriptions/ index.html) (viewed 26 March 2007).

Hallier H. 1896. Neue und bemerkenswerte pflanzen aus dem malaiischpapuanischen inselmeer. Annales du Jardin Botanique de Buitenzorg 13 276-326.

Page RDM. 2001. NEXUS Data Editor for Windows, A program to edit NEXUS format data files. http: //taxonomy.zoology.gla.ac.uk/rod/NDE/nde.html (last modified 13 September 2001).

Pimentel RA, Riggins R.1987. The nature of cladistic data. Cladistics 3: 201-209.

Qi L, Friis I, Wilmot-Dear CM. 2003. Pellionia. In: Flora of China Editorial Committee (eds), Flora of China. Volume 5 (Ulmaceae through Basellaceae): 122-127. Science Press, Beijing \& Missouri Botanical Garden Press, St. Louis.

Robinson CB. 1910. Philippine Urticaceae. The Philippine Journal of Science 5: 465-542.

Robinson CB. 1911. Philippine Urticaceae II. The Philippine Journal of Science 6: 299-314.

Schröter H, Winkler H. 1935. Monographie der gattung Elatostema s.l.: Allgemeiner teil. Repertorium specierum novarum regni vegetabilis $83: 1-71$, f. $1-44$.

Schröter H, Winkler H. 1936. Monographie der gattung Elatostema s.l.: Spezieller teil. Repertorium specierum novarum regni vegetabilis $83: 1-237$, f. 9-40.

Swofford DL. 2002. PAUP*. Phylogenetic Analysis Using Parsimony ( ${ }^{*}$ and other methods) v4.0b10. Sinauer Associates, Sunderland, Massachusetts, USA

Thiele K. 1993. The holy grail of the perfect characters: the cladistic treatment of morphometric data. Cladistics 9: 275-304.

Thiele K, Ladiges PY. 1988. A cladistic analysis of Angophora Cav. (Myrtaceae). Cladistics 4: 23-42.

Tukey JW. 1977. Box-and-whisker plots. Explanatory data analysis: 39-43. Addison-Wesley, Reading, MA.

Wang W-T. 1980a. Classificatio Specierum Elatostematis (Urticaceae). Bulletin of Botanical Laboratory of North-Eastern Forestry Institute 4, 7: 1-96. Wang W-T. 1980b. Classificatio Specierum Sinensium Pellionae (Urticaceae). Bulletin of Botanical Laboratory of North-Eastern Forestry Institute 6, 1: 4566.

Weddell HA. 1854. Revue de la famille de Urticacees. Annales des Sciences Naturelles; Botanique, Series 4: 173-212.

Weddell HA. 1856. Monographie de la famille des Urticées. Nouvelle Archieves du Muséum d'Histoire Naturelle 9: 1-400.

Weddell HA. 1857. Monographie de la famille des Urticées. Nouvelle Archieves du Muséum d'Histoire Naturelle 9: 401-592.

Weddell HA. 1869. Urticaceae. In: De Candolle A(ed), Prodomus systematis naturalis regni vegetabilis, vol. 16, part 1: 32-35. Masson, Paris,

Wilkinson L, Hill M, Miceli S, Birkenbeuel G, Vang E. 1992. Systat for Windows: Graphics, v5.1 Edition. Systat, Inc., Evanston, Illinois.

Winkler H. 1922. Die Urticaceen Papuasiens. Beiträge zur flora von Papuasien 8: 501-608. 